\title{
The methodological basement of the invention the model of formation the culture of the intersocial cooperation of the Pedagogical College students
}

\section{Методологічне підґрунтя розробки моделі формування культури міжособистісної взаємодії студентів педагогічного коледжу}

\author{
Tetyana Kozhushkina, \\ postgraduate \\ Alfred Nobel University, \\ 18 Naberezhna Sicheslavska, \\ Dnipro, 49000
} https://orcid.org/0000-0002-6114-1849 t.kozuskina@gmail.com
Тетяна Кожушкіна, аспірантка

\author{
Університет імені А. Нобеля \\ $\triangle$ вул. Січеславська
}

Набережна, 18, м. Дніпро, 49000

\begin{abstract}
The article has been devoted to the consideration of the methodological approaches which have been the basement of the invention the model of the formation the culture of the intersocial cooperation of the Pedagogical College students. It has been stated that in the conceptual version the model of the formation the culture of the intersocial cooperation of the Pedagogical College students has been based on the system and synergetic, cultural, axiological, communicative, personal approaches. It has been determined that the axiological approach provides the development of the axiological students' potential due to the interiorization of the value system which have been the orient of the future cultural and communicative activity, and they reflect its focus of the achievement the humanistic purposes and help with the socialization of the future expert.

It has been stated that the cultural approach provides the establishment of the student's personality as the subject and the object of the intersocial cooperation. It has been proved that system and synergetic approach integrate the philosophical and scientific ideas of the study the problem and it determines the common direction of the designing the model of the research with the allowances made for system peculiarities of the process and the specific of its content.

It has been stressed that the communicative approach allows to solve the content question, the organization of the formation process of the cultural intersocial cooperation, the methods, the means and technologies of the cooperation with students. It has been defined that personally orientated approach provides taking onto account the personal student's peculiarities, their abilities, creativity, which activate and stimulate the self-developing, selfeducation processes promoting the formation of the cultural personality in the process of the intersocial cooperation. From the perspective of the determined approaches the culture of intersocial cooperation has been observed from the point of its evolution and transformation of the content as the complex system which has contradictory and undulating peculiarities which have been realized due to the plenty of facts. The conclusion has been made, that the educational sphere of the Pedagogy College has the abilities for the realization of the system, synergetic, cultural, axiological, communicative, personal approaches in the process of the formation the culture of the intersocial cooperation.
\end{abstract}

Key words: the culture of the intersocial cooperation, system and synergetic approach, cultural approach, axiological approach, communicative approach. 
Постановка проблеми. У сучасних соціокультурних умовах суспільство пред'являє якісно нові вимоги до педагога: рівня освіти, профресіоналізму, ціннісних орієнтацій, духовно-моральної й комунікативної культури, що стають невід'ємною частиною його життєдіяльності. Ефективність професійної діяльності сучасного вчителя залежить від багатьох фракторів, серед яких особливе місце займає успішна культурно-комунікативна діяльність як основа гуманних взаємин, співпраці, досягнення взаєморозуміння і реалізації цілей та завдань професійної діяльності. Це підтверджує необхідність організації цілеспрямованого процесу формування культури міжособистісної взаємодії під час навчання студентів у педагогічному коледжі, який передбачає, передусім, розробку відповідної моделі зазначеного феномену. Наголошуємо, що створення моделі формування культури міжособистісної взаємодії студентів педагогічного коледжу потребує об'єктивності та надійності наукових висновків та залежить від загального підходу до розуміння сутності явищ і процесів, що досліджуються, тобто передбачає вибір теоретико-методологічних стратегій дослідження наукового фундаменту, з позиції якого пояснюються основні педагогічні явища, розкриваються закономірності, що вирішальним чином впливають на теоретичну інтерпретацію цих явищ у майбутньому (Наход, 2014). Отже, на сьогодні методологічні дослідження визначеної проблеми мають не тільки гносеологічне та онтологічне, але й практичне значення, оскільки достовірність, обґрунтованість, об'єктивність та ефективність наукового пошуку безпосередньо залежать від рівня та ступеня розробки методологічних аспектів окресленого питання.

Аналіз досліджень і публікацій. Проблема формування культури міжособистісної взаємодії вже кілька десятків років досліджується в теорії і практиці вищої освіти, що забезпечило створення системи комунікативного виховання і комунікативної дидактики. Міжособистісній взаємодії надається вирішальна роль у розвитку сутнісних сил особистості, її самореалізації, формуванню системи соціальних відносин тощо.

Вивченню комунікативної спрямованості педагогічної діяльності присвячені роботи Г. Андрєєвої, Л. Бєляєвої, Н. Волкової, С. Гіппіус, М. Каган, С. Кожушко, Н. Рачкова, Є. Рогова, Є. Руденського, В. Рижова, О. Тарнопольського, Г. Якушева та інших. Різні аспекти культури міжособистісної розглядають у своїх наукових працях Г. Арстангалєєва, І. Коваль, Л. Мохнар, Н. Мирончук, М. Рудь, В. Сморчкова, В. Соколова, В. Тернопільська, І. Тимченко, О. Фролушкіна, О. Яструб та ін. Вчені порізному обґрунтовують вибір методологічних підходів, що стають базою формування дослідженого феномену.

Так, Г. Арстангалєєва надає перевагу аксіологічному, системнодіяльнісному, культурологічному, особистісно-орієнтованому підходам. М. Рудь описує значущість комунікативного, системного та культурологічного підходів для процесу формування комунікативної культури майбутнього вчителя. О. Мазко до основних методологічних підходів, здатних оптимізувати процес формування культури педагогічної 
взаємодії майбутнього вчителя, відносить особистісно-орієнтований, діяльнісний, компетентнісний, системно-синергетичний, культурологічний та аксіологічний підходи. О. Яструб вважає, що доцільність цілісного сприйняття культури студентів, поєднання різних предметних сфер їх діяльності в процесі формування культури міжособистісної взаємодії в майбутніх учителів початкової школи в позааудиторній роботі забезпечуються реалізацією культурологічного, компетентнісного, акмеологічного підходів. О. Сутугін у процесі формування комунікативної культури наголошує на системному, особистісно-орієнтованому, компетентнісному, культурологічному та діяльнісному підходах. В. Сморчкова фрормує методологічну базу, включаючи до неї системний, культурологічний, комунікативний, етичний, особистісно-діяльнісний, семіотичний та синергетичний підходи.

Аналіз вищевказаних поглядів науковців дозволяє нам представити власне бачення системи методологічних підходів, на ґрунті яких побудована наша модель фрормування культури міжособистісної взаємодії студентів педагогічного коледжу.

Мета статті полягає в розкритті суті методологічних підходів, на яких базується модель фрормування культури міжособистісної взаємодії студентів педагогічного коледжу.

Виклад основного матеріалу. У нашому дослідженні враховуємо те, що методологія - це вихідні положення, реалізація яких є в основі здійснення теоретичної й практичної діяльності людини, а методологія педагогіки - це вчення про педагогічні знання, процеси його здобування, способи пояснення та практичного застосування з метою перетворення або вдосконалення педагогічної системи (Волкова, 2013). 3 огляду на це, вагомого значення в процесі формування культури міжособистісної взаємодії студентів педагогічного коледжу надаємо системносинергетичному, культурологічному, аксіологічному, комунікативному та особистісно-орієнтованому підходам. Розглянемо їх більш докладно.

Системно-синергетичний підхід обраний нами як методологічна основа, адже він інтегрує ідеї загальнофілософського та загальнонаукового вивчення проблеми та дозволяє розглядати культуру міжособистісної взаємодії як складну організовану педагогічну систему з усіма властивими їй ознаками. Зазначимо, що цей підхід сфрормувався в надрах природничо-наукових знань та згодом показав свої можливості в соціально-гуманітарних науках. Досить плідним він виявився в педагогіці, яка вивчає найскладніші явища дійсності - формування, організацію, розвиток, самоорганізацію і саморозвиток культури суспільства та окремої особистості.

За умов системного підходу будь-які об'єкти дослідження розглядаються не ізольовано, а у взаємозв'язку, розвитку, русі, а також як елементи деякої цілісної сукупності, пов'язані між собою певними відносинами, в результаті яких виникають загальні, цілісні властивості системи, що якісно відрізняються від властивостей ії елементів (Щуркова, 2002). Зазначений підхід спирається на переважання цілого відносно його 
частин, дозволяє виявити інтегративні системні властивості та якісні характеристики, побудувати структурні й функціональні моделі системи, виділити основні компоненти, визначити закономірності їх функціонування та принципи ефективної організації.

У рамках такого підходу процес формування культури міжособистісної взаємодії студентів педагогічного коледжу розглядається як система взаємопов'язаних компонентів (мети, змісту, методів, засобів, форм і результатів навчання), що $є$ цілісним утворенням. Центром такої системи $€$ особистість студента як цілісна, динамічна, унікальна, складна система, що саморозвивається та має потенційні здібності до самовдосконалення, самоуправління, самонавчання та самодіагностування, результати якості культурно-комунікативної освіти якої виявляються, зокрема, у сформованості культури міжособистісної взаємодії.

Синергетичний підхід робить акцент на самоорганізації системи та передбачає комплексне врахування зв'язків різних рівнів і форм між ії елементами, розвиток яких (зв'язків) посилює їх цілісність та ефективність, можливість багатоваріантного розвитку з урахуванням статистичних (імовірнісних) і динамічних законів і закономірностей (Воронкова, 2012). Послугування синергетичною методологією означає, що формування культури міжособистісної взаємодії студентів педагогічного коледжу відбувається в умовах неврівноваженості, нелінійності, незворотності в комунікативному освітньому середовищі, що $\epsilon$ системою реальних і модельованих міжособистісних та індивідуальних комунікативних задач i ситуацій. За таких позицій культура міжособистісної взаємодії студентів педагогічного коледжу є системою, що входить до складу системи більш високого порядку, представляючи собою один 3 найважливіших функціонально значущих елементів культури суспільства в цілому. Водночас вона має іманентну структуру власних елементів (аксіологічно-мотиваційний, змістово-теоретичний, операційно-практичний та рефлексивно-регулятивний), що визначають її внутрішню організованість, здатність до самоорганізації і розвитку.

Використання культурологічного підходу забезпечує розгляд процесу формування культури міжособистісної взаємодії через призму системоутворюючих культурологічних понять: культура, культурні зразки, культурна діяльність професійна культура, педагогічна культура, інтелектуальна культура, моральна культура тощо (Крилова, 2000: 65). Особливо це актуально сьогодні, коли освіта визначається як невід'ємна складова культуротворчого процесу, культуропровідна система, спрямована на розвиток особистості.

Зазначимо, що людина не лише розвивається в процесі засвоєння культури, а й поповнює та вдосконалює її (Зимня, 2004). Аналіз педагогічних явищ на широкому соціокультурному тлі обов'язково враховує локальну культурну ситуацію, конкретне культурне оточення, певне середовище, у якому формується особистість фахівця. Невід'ємною частиною цієї системи культури $є$ рідна культура, за допомогою якої студенти засвоюють цінності етносів, розвивають свою 
національну і міжнаціональну самосвідомість, а також толерантність до інших культурних феноменів. Отже, застосування культурологічного підходу допомагає розглядати культуру міжособистісної взаємодії студентів педагогічного коледжу з таких позицій:

- найвищою цінністю визнається особистість студента, здатна виконувати професійні завдання на основі засвоєних культурних смислів, значень природовідповідних, культуровідповідних, особистісноорієнтованих принципів, підходів і технологій, інтеріоризації гуманістичних цінностей;

-у побудові змісту процесу формування культури міжособистісної взаємодії реалізується гуманістична установка в розумінні соціальної функції людини, а також приділяється увага філософрському та методологічному осмисленню соціально-педагогічної науки і практики;

- освітній процес, освітнє середовище, освітній простір педагогічного коледжу мають необхідні засоби для культурнокомунікативного розвитку студента, в процесі якого він сам обирає цінності, норми, знання і зразки поведінки;

- культура міжособистісної взаємодії як одна зі складових загальнолюдської культури формується на індивідуально-особистісному рівні, а тому вимагає індивідуалізації процесів оволодіння та створення елементів культури в освітньому процесі;

- особливо важлива вираженість ціннісної спрямованості, яка є основним регулятором відбору та побудови змісту освіти з урахуванням основних досягнень людства й ціннісних орієнтацій конкретно-історичного періоду.

Таким чином, послугування культурологічним підходом насичує зміст та форми міжособистісної взаємодії культурними компонентами, дозволяє виявити соціокультурні проблеми під час міжособистісної взаємодії, вирішувати їх на основі принципів та норм сучасної моралі. Його важливість для формування особистості студента педагогічного коледжу вбачаємо в тому, що відбувається розвиток не лише професійної культури майбутнього фахівця, а й культури міжособистісної взаємодії як її складової, що уможливлює інтеграцію до системи світової і національної культур (Національна доктрина розвитку освіти, 2002). Цим забезпечується формування культурних цінностей, норм і багатовимірного погляду на їх сутність у процесі міжособистісної взаємодії.

Зміст культурологічного підходу поглиблюється положеннями аксіологічного підходу, що сформувався в межах філософського вчення про цінності, які в природі та реальному бутті людини виступають у ролі специфічної призми, через яку відбиваються соціально-психологічні процеси. За системою цінностей та ціннісних орієнтацій можна зрозуміти функціональну спрямованість та соціальну значущість будь-якого суспільного процесу як системи (Леонтьєв, 1992). Цінності виражають такі відносини між людьми, що не роз'єднують, не відчужують людину від інших, а навпаки об'єднують, збирають у спільноту будь-якого рівня. Ціннісні відносини не $є$ зовнішніми і примусовими, а внутрішніми і 
ненасильницькими. Саме до світу цінностей застосовне поняття “культура", яке постає як підсумок попередньої діяльності людини, що являє собою складну ієрархію ідеалів і смислів. Звідси цілком природним $€$ застосування аксіологічного підходу і до вивчення процесу формування культури міжособистісної взаємодії, адже, на думку сучасних вчених і практиків, цінності визначають змістовність та стратегічну спрямованість освіти, в тому числі і виховання майбутнього фахівця.

Аксіологічний підхід характеризує комунікативну установку як готовність особистості до ціннісно-спрямованої культурно-комунікативної діяльності. Специфіка провідних життєвих установок особистості виявляє тип загального ставлення до соціальної дійсності, до людей, їх відносин, до життя в цілому, що обумовлюють вибір певного сектора основних соціальних цінностей. 3 огляду на це моделювання процесу формування культури міжособистісної взаємодії в системі фахової підготовки студентів педагогічного коледжу передбачає розвиток їх аксіологічного потенціалу шляхом інтеріоризації системи цінностей, що служать орієнтиром культурно-комунікативної діяльності майбутнього педагога, відображаючи її спрямованість на досягнення гуманістичних цілей та допомагають у соціалізації фахівця.

3 позицій комунікативного підходу культура міжособистісної взаємодії розглядається як комунікативна діяльність, що виявляється у взаємодії суб'єкта з іншим суб'єктом, навколишнім світом в цілому. Відомо, що основи комунікативного підходу до вивчення феномену заклали Ю. Хабермас, К.Ясперс, О. Апель, М. Каган, які у своїх дослідженнях визначали, наскільки комунікація $€$ відкритою та базовою для культури загалом. Характеризуючи комунікативний підхід, І. Зимня зазначає, що він "дозволяє наочно уявити схему педагогічної взаємодії у всьому різноманітті ії ланок: джерело, ситуація, канал, зворотний зв'язок тощо” (Єрмоліна, 1991: 327). До понятійного апарату зазначеного підходу входять поняття: сорера комунікації, функції комунікації, комунікативна ситуація, комунікативне завдання. Серед функцій комунікативного підходу вчені виділяють: інформаційно-комунікативну, регуляційно-комунікативну та афективно-комунікативну, підкреслюючи обов'язковість власне комунікативного компонента як прийому і передачі повідомлення, регуляції поведінки та наявність певного відношення до ситуації (Ломов, 1975).

Комунікативний підхід вимагає дотримання таких умов його реалізації: забезпечення вільної комунікативної діяльності викладача і студентів, основним моментом якої $€$ постійний зворотний зв'язок, що забезпечує коригування їх діяльності; використання комунікативних технологій, специфіка яких у процесі формування культури міжособистісної взаємодії студентів педагогічного коледжу проявляється в способах, прийомах, вправах, техніках взаємодії суб'єктів освітнього процесу, спрямованих на розвиток професійно значущих комунікативних якостей; оволодіння культурою міжособистісної взаємодії як основним інструментом професійної діяльності і способом інтеріоризації смислів соціальної реальності, соціальних спільнот (нація, колектив, сім'я та ін.) і 
особистісних смислів майбутнього педагога.

Щодо особистісно-орієнтованого підходу, з його позицій культура міжособистісної взаємодії постає як спосіб, умова і результат всієї життєдіяльності людини, підкреслюючи важливість діяльності суб'єктів системи професійної підготовки майбутнього педагога у створенні комунікативного простору, де виникає, розвивається і проявляється культура міжособистісної взаємодії, формуються комунікативні якості і здібності людини. Звернення до особистості в їі діяльності дозволяє виявити внутрішньо особистісні психолого-педагогічні чинники та умови формування зазначеного феномену 3 орієнтацією на найбільш повну реалізацію комунікативного потенціалу особистості (Лісіна, 1985). Маємо на увазі комунікативну активність як найважливіший внутрішньоособистісний фактор розвитку культури міжособистісної взаємодії майбутнього педагога.

Особистісно-орієнтований підхід представляє собою цілеспрямоване ставлення педагога до студента як до особистості, самостійного, відповідального суб'єкта процесу навчання, і передбачає використання сукупності прийомів і методів, а також створення умов, за яких розвивається майбутній учитель, розкриваються його можливості для здійснення особистісно значущої діяльності. Зазначаємо, що освітнє середовище педагогічного коледжу має всі можливості для реалізації особистісно-орієнтованого підходу в процесі формування культури міжособистісної взаємодії, що відбувається шляхом: подання змісту навчання в стислому форматі у вигляді модулів; коригування обсягу навчального матеріалу щодо поглиблення, ускладнення або спрощення залежно від особистісних здібностей і професійних потреб студентів; збільшення частки самостійної роботи студентів під час засвоєння модулів, що сприяє формуванню готовності особистості до самоосвіти; контролю й оцінювання рівня особистісних досягнень кожного студента, що дозволяє організувати навчання таким чином, щоб кожен студент міг проявити себе як особистість, реалізувати свій творчий потенціал.

Конструктивна можливість реалізації особистісно-орієнтованого підходу в процесі формування культури міжособистісної взаємодії розкривається в створенні в педагогічному коледжі таких умов: наділення особистісним змістом культурно-комунікативної діяльності студентів, що забезпечить досягнення більш високих навчальних результатів та позитивним чином відобразиться на їхньому рейтингу; розвиток особистісних функцій суб'єктів освітнього процесу, серед яких прийняття студентами культурно-комунікативної діяльності, спрямованої на досягнення особистих результатів. Вважаємо, що розвиток особистісної функції самореалізації в процесі формування культури міжособистісної взаємодії додасть творчий характер різним видам навчальної діяльності студентів та забезпечить досягнення високого індивідуального кумулятивного індексу.

Висновки. Таким чином, культурологічний підхід разом 3 аксіологічним, системно-синергетичним, комунікативним та особистісноорієнтованим складають сутність методології нашого дослідження і визначають методологічні засади моделювання процесу формування 
культури міжособистісної взаємодії студентів педагогічного коледжу в системі фахової підготовки. Аксіологічний підхід забезпечує спрямованість освітнього середовища коледжу на формування соціокультурних цінностей і норм. Культурологічний підхід сприяє становленню особистості студента як суб'єкта та об'єкта міжособистісної взаємодії. Використання системно-синергетичного підходу дозволяє визначити загальний напрямок проектування моделі дослідження 3 урахуванням системних особливостей цього процесу та специфіки його змісту. Проекція основних положень і понять комунікативного підходу на наш об'єкт дослідження дозволяє вирішити питання змісту, організації формування культури міжособистісної взаємодії, методів, способів і технологій роботи зі студентами. Особистісно-орієнтований підхід забезпечує урахування індивідуальних особливостей студентів, їх здібностей, творчого потенціалу, які активізують та стимулюють процеси саморозвитку, самоосвіти та самовиховання, сприяючи фрормуванню культурної особистості під час міжособистісної взаємодії.

Вважаємо, що за умов послуговування визначеною методологічною базою процес формування культури міжособистісної взаємодії стає керованим та гармонійно збалансованим між зовнішніми впливами і внутрішніми процесами.

\section{Література}

1.Волкова Н. П. Моделювання професійної діяльності у викладанні навчальних дисциплін у вишах: монографія / Н. П. Волкова, О. Б. Тарнопольський; за заг. та наук: ред. О. Б. Тарнопольського. - Д.: Дніпропетр. ун-т ім. А. Нобеля, 2013. - 228 с.

2.Воронкова В. Г. Формування синергетично-рефлексивної моделі самоуправлінського суспільства: цивілізаційний контекст / В. Г. Воронкова // Гуманітарний вісник Запорізької державної інженерної академії: [зб.наук.пр.] Запоріжжя: Вид-во ЗДІА, 2012. - Випуск № 49. - С. 17-28.

3.Ермолина Г. К. Идеал справедливости и действительность / Г. К. Ермолина. Иваново, 1991. - 102 с.

4.Зимняя И. А. Педагогическая психология: Учебник для вузов / И. А. Зимняя. - Изд. второе, доп., испр. и перераб. - М.: “Логос", 2004. - 384 С.

5.Крылова Н. Б. Культурология образования / Н. Б. Крылова. - М.: Народное образование, 2000. - 272 с.

6.Леонтьев Д. А. Методика изучения ценностных ориентации / Д. А. Леонтьев. - М.: Смысл, 1992. - 17 с.

7.Лисина М. И. Общение и речь: развитие речи у детей в общении со взрослыми / М. И. Лисина. - М., 1985. - 207 с.

8.Ломов Б. Ф. Общение как проблема общей психологии / Б. Ф. Ломов // Методологические проблемы социальной психологии. - М., 1975. - С. 124-135.

9.Національна доктрина розвитку освіти // Офіційний вісник України: щотижневий збірник актів законодавства. - № 16. - 2002. - С. 11-24.

10. Наход С. А. Методологічні підходи до розробки технології фрормування прогностичних умінь практичних психологів засобами інтерактивних технологій / С. А. Наход // Вісник Дніпропетровського університету імені Альфреда Нобеля. Серія “Педагогіка і психологія”. Педагогічні науки. - 2014. - № 2 (8). - С. 69-76.

11. Щуркова Н. Е. Педагогическая технология / Н. Е. Щуркова. - М.: Педагогическое общество России, 2002. - 224 с. 


\section{References}

1.Volkova, N. P. \& Tarnapolskyi, O. B. In O. B. Tarnapolskyi (Ed.). (2013). Modeliuvannia profesiinoi diialnosti u vykladanni navchalnykh dystsyplin u vyshakh [Modeling of professional activity in the teaching of academic disciplines in higher education]. Dnipropetrovsk, Dnipropetrovskyi universytet imeni A. Nobelia Publ., 228 p. (In Ukrainian).

2.Voronkova, V. H. (2012). Formuvannia synerhetychno-refleksyvnoi modeli samoupravlinskoho suspilstva: tsyvilizatsiinyi kontekst [Formation of a synergeticreflexive model of self-governing society: civilization context]. Humanitarnyi visnyk Zaporizkoi derzhavnoi inzhenernoi akademii [Humanitarian Bulletin Zaporizhzhya State Engineering Academy]. Zaporizhzhia, Zaporizka derzhavna inzhenerna akademiia Publ., issue 49, pp. 17-28 (In Ukrainian).

3.Ermolina, H. K. (1991). Ideal spravedlivosti i deistvitelnost [The ideal of justice and reality]. Ivanovo, 102 p. (In Russian).

4.Zimniaia, I. A. (2004). Pedahohicheskaia psikholohiia [Pedagogical psychology]. Moskva, Lohos Publ., 384 p. (In Russian).

5.Krylova, N. B. (2000). Kulturolohiia obrazovaniia [Culturology of education]. Moskva, Narodnoe obrazovanie Publ., 272 p. (In Russian).

6.Leontev, D. A. (1992). Metodika izucheniia tsenostnykh orientsatsii [Methodology for the study of value orientations]. Moskva, Smysl, 17 p. (In Russian).

7.Lisina, M. I. (1985). Obshchenie i rech : razvitie rechi u detei v obshchenii so vzroslymi [Communication and speech: the development of speech in children in communication with adults]. Moskva, 207 p. (In Russian).

8.Lomov, B. F. (1975). Obshchenie kak problema obshchei psikholohii [Communication as a problem of general psychology]. Metodolohicheskie problemy sotsialnoi psikholohii [Methodological problems of social psychology]. Moskva, pp. 124135 (In Russian).

9. Natsionalna doktryna rozvytku osvity (2002). [National Doctrine of Education Development] Ofitsiinyi visnyk Ukrainy [Official Bulletin of Ukraine], no. 16, pp. 11-24 (In Ukrainian).

10. Nakhod, S. A. (2014). Metodolohichni pidkhody do rozrobky tekhnolohii formuvannia prohnostychnykh umin praktychnykh psykholohiv zasobamy interaktyvnykh tekhnolohii [Methodological approaches to the development of technology for the formation of prognostic skills of practical psychologists by means of interactive technologies]. Visnyk Dnipropetrovskoho universytetu imeni Alfreda Nobelia. Pedahohika i psykholohiia, no. 2 (8), pp. 69-76 (In Ukrainian).

11. Shchurkova, N. E. (2002). Pedahohicheskaia tekhnolohiia [Pedagogical technology]. Moskva, Pedahohicheskoe obshchestvo Rossii Publ., 224 p. (In Russian).

\section{АНОТАЦІЯ}

Стаття присвячена аналізу методологічних підходів, що склали науковий фундамент розробки моделі формування культури міжособистісної взаємодії студентів педагогічного коледжу. Встановлено, що в концептуальному плані модель формування культури міжособистісної взаємодії студентів педагогічного коледжу базується на системно-синергетичному, культурологічному, аксіологічному, комунікативному, особистісноорієнтованому підходах. З'ясовано, що аксіологічний підхід забезпечує розвиток аксіологічного потенціалу студентів педагогічного коледжу шляхом інтеріоризації системи цінностей, що служить орієнтиром їх майбутньої культурно-комунікативної діяльності, відображаючи ї̈ спрямованість на досягнення гуманістичних цілей, допомагає в соціалізації майбутнього фрахівця. Визначено, що культурологічний підхід сприяє становленню особистості 
Серія: Педагогічні науки. - Вип.1. - Бердянськ : БДПУ, 2019. - 406 с.

студента як суб'єкта та об'єкта міжособистісної взаємодії. Обгрунтовано, що системно-синергетичний підхід інтегрує ідеї загальнофрілософрського та загальнонаукового вивчення проблеми $i$ визначає загальний напрямок проектування моделі дослідження з урахуванням системних особливостей цього процесу та специфіки його змісту. Наголошено, що комунікативний підхід дозволяє вирішити питання змісту, організації процесу формування культури міжособистісної взаємодії, методів, способів і технологій роботи зі студентами. Встановлено, що особистісно-орієнтований підхід забезпечує урахування індивідуальних особливостей студентів, їх здібностей, творчого потенціалу, які активізують та стимулюють процеси саморозвитку, самоосвіти та самовиховання, сприяючи формуванню культурної особистості в процесі міжособистісної взаємодії. З позицій виокремлених підходів культура міжособистісної взаємодії розглядається 3 точки зору ї еволюції та трансфрормації змісту як складна організована система, яка має суперечливі та хвилеподібні властивості, що детермінуються багатьма чинниками. Зроблено висновок, що освітнє середовище педагогічного коледжу має всі можливості для реалізації системно-синергетичного, культурологічного, аксіологічного, комунікативного, особистісно-орієнтованого підходів у процесі формування культури міжособистісної взаємодії студентів.

Ключові слова: культура міжособистісної взаємодії; системносинергетичний підхід; культурологічний підхід; аксіологічний підхід; комунікативний підхід. 